\title{
Improving the efficiency of an air conditioning system using a fire water tank as
} thermal accumulator

Renedo CJ, Ortiz A, Pérez S, Delgado F, Fernández I, Carcedo J

Electrical and Energy Engineering Department, University of Cantabria, E.T.S.I.I. y T, Avda. de los Castros, 39005 Santander, Spain

Corresponding autor Carlos J Renedo

renedoc@unican.es

Telephone number: 0034942201382

\begin{abstract}
This paper studies the substitution of air condensation by water condensation in the chiller of a University building. This building has a surface about $30000 \mathrm{~m}^{2}$, is located in a city of the Spanish north coast, and refrigeration is needed for six months a year. In this paper, the novelty lies in the cooling system of the condensation water, since the typical cooling tower is not going to be considered, instead the domestic cold water consumed in the building would be used to cool the chiller condensing water. As the domestic water consumption in the building is not constant and nor coincident with the cooling requirements of the chiller, the use of the fire water tank as heat storage was proposed. Thus, the chiller is cooled by the water contained in the fire tank and this fire water is then cooled by the domestic water. With this solution, the reduction in the annual energy consumption of the chiller is around $18.6 \%$. The requirements to implement this solution in buildings are: cool water for air conditioning is produced in a
\end{abstract}


centralized way, a relatively high building domestic water demand and a building fire water tank.

\section{Practical application}

The solution proposed in this paper can contribute to primary energy savings by improving the energy efficiency of HVAC systems. It can be adopted in all buildings that require refrigeration, have a significant consumption of domestic water and have a water storage tank for fire or other uses. The article includes the preliminary design of a water-water heat exchanger as a possible solution for cooling the chiller, but alternative solutions could be adopted. Finally, a cost benefit analysis has been performed, showing that the proposed solution is feasible.

\section{Keywords}

Air conditioning, chiller, water condensation, energy efficiency, thermal storage

\section{Nomenclature}

$\begin{array}{ll}\mathrm{C}_{\mathrm{p}} & \text { Specific heat } \\ \mathrm{CD} & \text { Cooling Demand } \\ \text { COP } & \text { Coefficient of Performance } \\ \% \mathrm{CD} & \text { Schedule of daily CD in \% } \\ \mathrm{M}_{\mathrm{W} \text { Tank }} & \text { Water mass in Fire Water Tank } \\ \text { NCV } & \text { Net Calorific Value } \\ \text { NG } & \text { Natural Gas } \\ \text { NGC } & \text { Natural Gas Consumption } \\ \text { QCond w } & \text { Heat provided to the Tank through the water condenser }\end{array}$


Temperature

TW

Tap Water (Domestic Water)

TWD

Tap Water Demand (Domestic Water Demand)

Tank

Fire Water Tank

$\mathrm{T}_{\text {Tank }}$

Temperature of Fire Water Tank

$\mathrm{T}_{\mathrm{TW}} \mathrm{db}$

Temperature of TW distributed in the building

$\mathrm{T}_{\mathrm{TW}}$ in

Inlet temperature of TW in the building from city network

$\Delta \mathrm{T}_{\mathrm{T}-\mathrm{Cond}}$

Temperature Increment in the tank as a result of the heat supplied by the condenser

$\Delta \mathrm{T}_{\mathrm{T}-\mathrm{TW}}$

Temperature Increment in the tank as a result of heat removed by the TW

$\Delta \mathrm{T}_{\mathrm{TW}}$

Temperature increment allowed in TW to pass through the heat exchanger located in the tank

WD

Water Demand

$\rho_{\mathrm{W}}$

Density of water

\section{Subscripts}

$\begin{array}{ll}\text { a } & \text { air or air condensation } \\ \mathrm{db} & \text { distributed in the building } \\ \text { in } & \text { inlet from city network } \\ \text { w } & \text { water or water condensation } \\ \text { (i) } & \text { at hour i } \\ \text { (d) } & \text { daily }\end{array}$

\section{Introduction}


The energy consumption in buildings has increased considerably in recent years for developing and developed countries. The improvement in quality of life and comfort requirements of buildings users has led the energy consumed in the building sector to reach significant values, regarding national energy consumption ${ }^{1}$. In particular, in the European Union this value reaches $40 \%{ }^{2}$. In buildings, energy is consumed primarily to power the following systems: lighting, transportation, appliances and computers, domestic hot water, heating and air conditioning. Depending on the usage profile and the weather, the latter service can represent more than $25 \%$ of the annual energy consumed in commercial buildings, where energy consumption in this system is mainly for 3: cold water production, and fluid movement through the building (water and/or air), with the majority of consumption in water chillers.

The energy consumption of air conditioning systems in buildings and the percentages over the national energy consumption vary from one country to another ${ }^{1}$. In Spain, according to the Spanish Ministry of Industry ${ }^{4}$, the energy consumption of air conditioning systems account for approximately $2.5 \%$ of national energy consumption, Fig.1.

Figure 1. Spanish energy consumption in buildings

The reduction of the energy consumption of air conditioning in buildings has been extensively studied ${ }^{5,6}$. Currently, this reduction can be carried out mainly with three techniques: reducing the heat demand of the building, recovering energy, and using more efficient HVAC systems. In these fields, multiple research works have been conducted. 
In the field of thermal demand reduction in buildings, two main groups of solutions can be highlighted: (1) the use of systems that allow the reduction of the heat input associated to solar radiation: solar shades, venetian or vertical blinds ${ }^{7}$, outer vegetation ${ }^{8}$ and more recently, smart windows ${ }^{9}$; and (2) the use of water evaporation systems outside the building, so as to remove part of the thermal load before entering the building; in this category several possibilities has been studied: spray systems ${ }^{10}$, water film on glazed façades ${ }^{11}$ and evaporative walls ${ }^{12}$.

In the field of heat recovery, studies considering many types of heat exchangers were performed, such as: fixed-plate, heat pipes ${ }^{13}$ or rotary wheel; a review of these works can be found in ${ }^{14}$. In addition, new techniques such as the use of the heat released in the condensation of the chiller to produce domestic hot water ${ }^{15}$, or the use of the extraction air to cool the condenser of the chiller ${ }^{16}$, have been also explored.

In order to increase the efficiency of the air conditioning system, several concepts have been studied, such as: free cooling ${ }^{17,18}$ and free cooling coupled with heat storage systems ${ }^{19}$; night ventilation ${ }^{20}$; using evaporative cooling ${ }^{21-23 ;}$ coupling the buildings with earth heat exchangers ${ }^{22,24,25}$; employing chillers with: two compressors ${ }^{26}$, variable-speed compressor ${ }^{27}$, electronic expansion valve ${ }^{27,28}$, variable refrigerant flow systems ${ }^{24,29,30}$, or with new refrigerants ${ }^{31}$; using absorption or adsorption chillers, either driven by solar energy ${ }^{32-34}$ or waste heat ${ }^{35,36}$; replacement of dry cooling towers by evaporative cooling towers ${ }^{37-39}$; improvement of control systems ${ }^{40-44}$; improvement of chiller condensation using swimming pools as heat links ${ }^{45}$, or even using aquifers as thermal storage ${ }^{46}$. In a recent review work ${ }^{47}$, different aspects that contribute to the energy efficiency on air conditioning systems were analyzed: novel cooling devices, innovative system designs and integration, and operational management and control. 
It is difficult to compare the improvements achieved with the above mentioned systems; this is mainly due to three reasons: studies have been performed on different types of buildings with different usage profiles, the weather of the areas in which they are located are not similar and efficiency parameters used are not the same. For example in some cases improvements of performance of the chiller or the compressor are proposed whereas in others the reduction of the thermal load, whether the total building or ventilation only, is considered. However, Table 1, in which the improvements obtained with the previously discussed systems offer, is presented.

Table 1. Achieved improvements with different proposals applied to HVAC systems There are other proposals which, although do not always produce energy savings, contribute to reduce the cost of the energy consumed. In this line, thermal storage systems have been studied ${ }^{48}$, typically associated with cooling night production, where the electric rate is more favorable ${ }^{49}$.

This work focuses on improving the efficiency of the system by increasing the chiller performance. This can use water or air condensation, the first of them has better performance ${ }^{50}$. This is because: (1) the cooling of the machine is carried out at lower temperatures, as in summer the water temperature is lower than the air temperature, and (2) the required temperature differential in the condenser between the refrigerant and heat-absorbing medium can be lower, since the water convection coefficient is several times higher than the one of the air ${ }^{51}$. Given the above, the difference between condensation and evaporation temperatures of coolant is lower in water condensing chillers, and therefore these machines have better Coefficient of Performance (COP), Eq.1 ${ }^{50}$. 
COP $=\frac{\text { Usefull Refrigerating Effect }}{\text { Net Energy Applied }}$

Eq.1

The problem with the cooling of condensers with water is the need for sufficient flow of cool water at the time in which building cooling demand (CD) occurs. This is usually solved by installing a closed circuit for the cooling of condensation water in cooling towers, and it can be classified according to: closed or open, and evaporative or dry ${ }^{37}$, 38. The evaporative type shows better performance, but has higher maintenance because of Legionella problems ${ }^{38}$. The installation of this auxiliary cooling circuit for the condenser presents a performance that reduces the potential energy improvement in the facility, and in addition represents an extra cost.

This work follows the same line of ${ }^{45}$, which studies the use of swimming pools as sinks for the reject heat in the condensation; however, public buildings usually do not have this type of facility. For this goal; air condensation in the chiller will be substituted by water condensation without a cooling tower. In this scheme, the domestic water demand (TWD) is used to cool the chiller. This has the disadvantage that the water consumption of buildings is neither constant nor coincident in time with the cooling requirements of the chiller ${ }^{52}$. In order to harmonize this temporal mismatch (batch process) ${ }^{53}$ the fire water tank is going to be used as an intermediate heat storage. This article includes an analysis of the system, showing $18.6 \%$ reduction in the annual energy consumption of the chiller. A sensitivity analysis has been performed that takes into account four aspects: (1) variation in water demand (WD) of the building, (2) variation of the supply water temperature, (3) change in distribution temperature of domestic water (TW) inside the building, and (4) increased CD.

\section{Case study}


The building studied is located in Santander, Spanish city located on the coast of Cantabrian Sea. The prevailing weather in the city is shown in Table $2^{54-56}$, and the building needs cooling from May to October. The building was built in 1997, belongs to the University of Cantabria, and has a footprint of approximately $9500 \mathrm{~m}^{2}$, with a total of $30000 \mathrm{~m}^{2}$ distributed over five floors. It has three blocks, the east and the west are occupied by Law and Economics Faculties respectively (classrooms, offices, meetings rooms, etc.), and the central one that is devoted to common services of both Faculties (cafeteria, restaurant, conference rooms, library, etc.). Inside the east and west blocks there are small enclosed atriums with a skylight, with approximately $80 \mathrm{~m}^{2}$ in each block. Between the Law and Economics Faculties and the central block, there are two more enclosed atriums with a skylight of $400 \mathrm{~m}^{2}$ each one. The two lower floors are smaller than the upper ones since the building is adapted to the mountainous topography of the terrain, Fig 2. The building is open between 8:00 am and 9:00 pm, and every day 4000 people (teachers, researchers, trainees, support and services staff, and students) can be inside intermittently.

Table 2. Santander climate data

Figure 2. Plan and elevation of the building

In the blocks corresponding to the two Faculties, there are classes both in the morning and in the afternoon. Annually, classrooms are highly occupied during both terms, starting from $1^{\text {st }}$ September and finishing $15^{\text {th }}$ July, they are virtually empty the rest of the year, because the teaching is reduced only to some summer courses. 
In the Faculties there are some areas, like computer rooms, that need cooling the whole year, they are equipped with unitary air conditioners. This part of the system, because of its low power and its dispersion in the building, has not been considered in this work.

In the central block the air conditioning is utilised primarily to condition the library. This space is occupied throughout the morning, suffering a decline in occupancy around lunchtime (around 2:00 pm in Spain), which again increases from 3:30 pm. The annual occupancy is greatest just before and during examination periods ( $15^{\text {th }}$ January to $28^{\text {th }}$ February, $15^{\text {th }}$ May to $30^{\text {th }}$ June and from $20^{\text {th }}$ August to $15^{\text {th }}$ September), and it is reduced the following month to these periods.

The cooling system of the building demands cold water at $7-12^{\circ} \mathrm{C}$, which is produced in a chiller. The main characteristics of the chiller are: the refrigerant is $407 \mathrm{C}$; the compressor is driven by a natural gas (NG) engine; the evaporator is a tubular and shell heat exchanger; and the air-cooled condenser is comprised of five fans consuming $11 \mathrm{~kW}$ of power ${ }^{57}$.

The water consumption in the building meets the demands of: toilets, general cleaning services, and cleaning of cafeteria and restaurant. It occurs mainly on working days, and coinciding with certain demand peak periods where there are rest times for students between the changes of the different classes.

Table 3 provides the data supplied by the Facilities Service of the University with the average NG consumption (NGC) of the chiller compressor over the past 5 years, and TWD ${ }^{58}$. This includes the working days of the month and the TW inlet temperature in the building from the city network ( $\mathrm{T}_{\mathrm{TW}}$ in ${ }^{59}$. 
Table 3. Natural gas consumed by the chiller, water demand and water inlet temperature in the period of building cooling.

The building has a fire water tank constructed of concrete, with a capacity of approximately $50 \mathrm{~m}^{3}(7.5 \times 4.5 \times 1.5 \mathrm{~m})$. This is open, and is housed in a room with exterior openings for natural ventilation of the room. The water entering the tank is controlled by a float, which is responsible for maintaining a constant level of water in the tank.

\section{Proposed Facility}

For the design of the facility, the substitution of air condensation by water condensation in the chiller has been studied; water condensation being energetically more favorable since it provides a higher COP by lowering the condensation temperature of the refrigerant fluid.

The scheme of the new system is shown in Fig 3. In order to undertake this design it is necessary: (1) to install in the chiller a water condenser in parallel with the current one of air, (2) to install a closed-loop water system (C.L.W.) for cooling the condenser, this loop connects the condenser with the fire water tank and consists of: pipes, pump, valves, filters, etc., (3) to build and place a water-water heat exchanger to cool the water in the tank with the domestic water consumed by the building, and (4) to install a water cooler to serve, if necessary, as auxiliary cooling of the tank.

Figure 3. Design scheme of the proposed system 
The new water-water exchanger could be a simple bundle of tubes immersed in the tank and for these tubes circulate the water consumed by the building, Fig 4 . The urban network supplies water from a reservoir located about $40 \mathrm{~m}$ above the level of the building, and therefore the incoming water has sufficient pressure to overcome the pressure losses caused by the installation of the heat exchanger before of the building water network. In the case that a crack appears in the heat exchanger, the urban network pressure would cause leakage from the network water into the tank, therefore the domestic water distributed in the building will be never polluted.

Figure 4. Scheme of the immersion heat exchanger in the fire water tank

This heat exchanger can be sized using some of the numerous methods for calculating the heat transfer coefficient. In this case, the flow inside the pipes will lead to forced convection while the external flow will lead to natural convection.

The internal heat transfer coefficient can be determined from Dittus-Boelter correlation. Taking into account de value of the Reynolds number and the Prandtl number, the Nusselt number can be calculated and then the convective coefficient. In this case, $\mathrm{h}_{\mathrm{ci}}$ is about $5 \cdot 10^{3} \mathrm{~W} /\left(\mathrm{m}^{2} \mathrm{~K}\right)$. The external heat transfer coefficient can be estimated from the Rayleigh number; in this case, $h_{c e}$ is about $5.5 \cdot 10^{2} \mathrm{~W} /\left(\mathrm{m}^{2} \mathrm{~K}\right)$. Considering the thinness of the pipes $(1 \mathrm{~mm})$ and the high thermal conductivity of the copper (395 $\mathrm{W} /(\mathrm{m} \cdot \mathrm{K}))$, its thermal resistance is negligible compared to convection one.

Finally, the LMTD method (Logarithmic Mean Temperature Difference) can be used to determine the effective surface of the heat exchanger. In summary, the heat exchanger shown in Fig 4 would consist of two layers of 120 copper pipes 6/8 mm diameter (inside/outside) and $4 \mathrm{~m}$ long. These results show the technical feasibility of the 
proposed solution since such a heat exchanger could be placed into the existing fire tank.

It could be also possible to use a plate heat exchanger, through which circulate the domestic water and the tank water. However, the purpose of this paper is not the mechanical calculation of this element, but studying the technical feasibility of the proposed system.

The water temperature in the tank must be low enough in order to be available in case of fire without risk of cavitation in pumps, and also to prevent eventual Legionella problems. For this, three conditions must be fulfilled: (1) it should not suffer daily increments, so that if the heat accumulated by the condensation of the chiller exceeds heat that can be daily removed by the domestic water of the building, it would be necessary to cool the water on the tank, this can be performed at night with the water cooler, (2) it must not be exceed a certain value at any time of the day, in this case $30^{\circ} \mathrm{C}$ is set, if this value is exceed, the water condensation should be stopped and it should be returned to condense with air, and (3) in the unlikely case of a fire in the building, the chiller could work using the pre-existing condensation system.

\section{Mathematical modelling}

In this section, the hourly consumption of NG is modeled considering the chiller is cooled using the fire water tank. This requires knowing three aspects:

- The hourly demand of air conditioning. It has been determined taking into account: The hourly demand profile, the NG consumption and the chiller COP in the current air-cooled system.

- The operating parameters of the chiller, which have been obtained from the technical data sheet of the machine. 
- The fire water temperature, that has been calculated taking into account the three following factors: The initial fire water temperature, the heat supplied by the chiller condenser and the heat removed by the domestic water used in the building.

The influence of gains and losses to the environment has not been considered due to the fact that gains are negligible compared to losses when calculating the fire water temperature. According to Table 2 and taking into account that the maximum expected fire water temperature is about $21^{\circ} \mathrm{C}$, gains from the environment would be about 0.35 $\mathrm{kW}$ whereas losses would be about $2.08 \mathrm{~kW}$. Gains are mainly due to convective heat transfer from air to water, while losses are mainly due to water evaporation, whose amount can be determined from Bernier equation. Therefore, not considering these effects leads to a more conservative design. Finally, knowing the chiller new operating conditions with water condensation, the COP and the NGC could be calculated.

Schedules of cooling demand $\left(\% \mathrm{CD}_{(\mathrm{i})}\right)$ and TWD must be first established, Fig 5 . For this reason, the daily data of NGC and TW have been collected, Table 2, and typical hourly profiles of this type of buildings have been considered ${ }^{60,61}$, with the following exceptions: (1) in Spain is usual to stop for lunch between 2:00 pm and 3:30 pm, and therefore at this time heated spaces are relatively empty, significantly lowering the CD, (2) the occupation of the building in the afternoon and evenings is significantly lower than in the morning, and (3) at the end of the day the building is empty and does not require cooling, however there is a small water consumption demanded by the building cleaning service.

Figure 5. Profiles of daily demands for cooling and domestic water 
The daily cooling demand, $C D_{(\mathrm{d})}$, has been determined considering: The hourly COP of the air-cooled chiller, $\mathrm{COP}_{a(\mathrm{i})}$, the gas engine performance, NGC, Table 3, and NG net calorific value $\left(\mathrm{NCV}_{\mathrm{NG}}\right)$, Eq 2; in which it has been considered a value of $\mathrm{NCV}_{\mathrm{NG}}$ provided by the company, $10.66 \mathrm{kWh} / \mathrm{Nm}^{3}{ }^{62}$, and a performance of the chiller gas engine, $0.335 \%{ }^{63}$.

$\mathrm{CD}_{(\mathrm{i})}=\mathrm{COP}_{\mathrm{a}(\mathrm{i})} \cdot$ Gas Engine Effiency $\cdot \mathrm{NGC}_{(\mathrm{i})} \cdot \mathrm{NCV}_{\mathrm{NG}}$ $C D_{(\mathrm{d})}=\sum_{\mathrm{h}=1}^{24} \mathrm{CD}_{(\mathrm{i})}$

The $\mathrm{COP}_{\mathrm{a}(\mathrm{i})}$ simulation has been performed with the software DUPREX Version 3.2 considering: (1) outside air temperature, which was calculated with the average monthly temperature and the average daily oscillation, Table 2, (2) temperature variations between the refrigerant and the air in the condenser of $15^{\circ} \mathrm{C}{ }^{64}$, and (3) temperature variations between the refrigerant and the water cooled in the evaporator of $7^{\circ} \mathrm{C}^{64}$.

The adjustment of simulation parameters for COP calculation, such as: pressure losses in condenser, evaporator and suction line, superheat in evaporator and in suction line, condenser subcooling, and compressor isoentropic efficiency, was performed considering a COP in the chiller of 2.93 , in nominal working conditions ${ }^{57}$. These are: $251 \mathrm{~kW}$ of cooling production, a NGC of $24 \mathrm{Nm}^{3} / \mathrm{h}$, an air temperature in the condenser of $35^{\circ} \mathrm{C}$, and $12^{\circ}$ and $7^{\circ} \mathrm{C}$ as input and output temperatures of the cooled water. This agrees with the Eq.3.

$\left.\mathrm{COP}\right|_{\text {Nominal }}=\frac{\text { Cooling Capacity }[\mathrm{kWh}]}{\mathrm{NGC}\left[\mathrm{Nm}^{3}\right] \cdot \mathrm{NCV}_{\mathrm{NG}}\left[\mathrm{kWh} / \mathrm{Nm}^{3}\right] \cdot \text { Gas Engine Efficiency }}$ 
To calculate the $\mathrm{CD}_{(\mathrm{d})}$ value, the $\% C D_{(\mathrm{i})}$ value, Fig 5 . has been taken into account. This

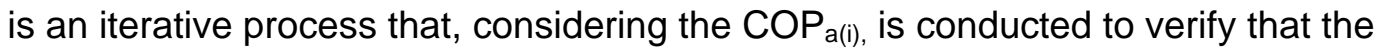
$\mathrm{NGC}_{(\mathrm{d})}$ obtained coincides with that of Table 3.

Then, the hourly cooling demand was established for the building, $\mathrm{CD}_{(\mathrm{i})}$, Eq.4. For this, it has been considered: $\mathrm{CD}_{(\mathrm{d})}$, and $\% \mathrm{CD}_{(\mathrm{i})}$, Fig 5 .

$\mathrm{CD}_{(\mathrm{i})}=\mathrm{CD}_{(\mathrm{d})} \% \mathrm{CD}_{(\mathrm{i})}$

Eq.4

The NGC with air condensation has been calculated each hour, $\mathrm{NGC}_{\mathrm{a}(\mathrm{i})}$, considering: $\mathrm{NGC}_{\mathrm{a}(\mathrm{d})}$, Table 2, the $\% \mathrm{CD}_{(\mathrm{i})}$, Fig 5, and the COP simulated hourly, COPa(i), Eq.5.

$$
N G C_{a(i)}=N G C_{a(d)} \cdot \frac{\% \mathrm{CD}_{(i)} \cdot \operatorname{COP}_{a(i)}}{\sum_{i=1}^{24} \% \mathrm{CD}_{(\mathrm{i})} \cdot \operatorname{COP}_{\mathrm{a}(\mathrm{i})}}
$$

With the proposed facility, condensation is performed with water, and in order to simulate the new COP, COP ${ }_{\mathrm{w}}(\mathrm{i})$, the only variations considered respect to the air condensation scheme have been: a temperature difference in the condenser between the water and the refrigerant of $7^{\circ} \mathrm{C}{ }^{62}$, and a temperature difference of $7^{\circ} \mathrm{C}$ between the water in the tank and the water inlet in the supply network of the building, Table 3. In this case, the condensation water is the content of the tank, and its temperature, $T_{\text {Tank, }}$ is variable throughout the day, as it depends on: the initial temperature of the tank, the temperature increment provided in the tank by the chiller condensation, $\Delta T_{T}$. cond, and the decrease in temperature experienced by the tank due to the heat removed by TWD, $\Delta \mathrm{T}_{\mathrm{T}-\mathrm{TW}}$. Therefore, the $\mathrm{COP}_{\mathrm{w}}$ (i), with the proposed installation depends on $\mathrm{T}_{\text {Tank }}$ at the end of the previous hour. 
With regard to the tank water temperature at the start of the day, $\mathrm{T}_{\text {Tank o, }}$, it has been considered equal to the one of the city water supply network, Table 3 , this is because:

(1) the room in which the tank is located has large openings to the outside, which favors the evaporation of the water contained in the tank, so there is natural evaporative cooling in the tank, (2) the water consumption performed nightly by the cleaning service, and (3) natural cooling occurs on non working days and weekends. The thermal losses in the water distribution pipeline between the condenser and the storage tank have not been considered, this effect contributes to reduce the heat input to the tank, and hence to reduce $\mathrm{T}_{\text {Tank. }}$.

The $T_{\text {Tank }}$ at the end of each hour, $\mathrm{T}_{\text {Tank (i) }}$, is calculated considering: the temperature at the end of the previous hour, $\mathrm{T}_{\text {Tank (i-1) }}$, the temperature increment suffered by the heat

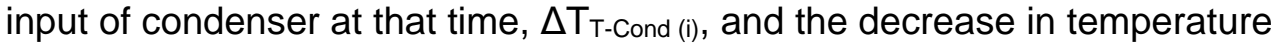
experienced in the tank, due to the heat removed by the water consumed in the building at that time, $\Delta \mathrm{T}_{\mathrm{T}-\mathrm{TW}(\mathrm{i})}$, Eq.6.

$$
\mathrm{T}_{\text {Tank (i) }}=\mathrm{T}_{\text {Tank (i-1) }}+\Delta \mathrm{T}_{\mathrm{T}-\text { Cond (i) }}-\Delta \mathrm{T}_{\mathrm{T}-\mathrm{TW} \mathrm{(i)}} \quad \text { Eq.6 }
$$

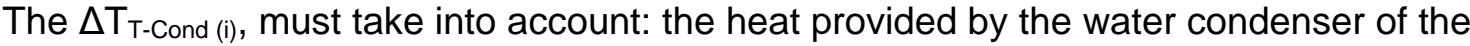
chiller, $\mathrm{Q}_{\text {cond w (i) }}$, the volume of water in the tank, $\mathrm{M}_{\mathrm{w} \text { Tank, }}$ and the specific heat of water, $\mathrm{C}_{\mathrm{p}}$, Eq.7.

$$
\Delta \mathrm{T}_{\mathrm{T}-\text { Cond (i) }}\left({ }^{\circ} \mathrm{C}\right)=\frac{\mathrm{Q}_{\text {Cond } \mathrm{w}(\mathrm{i})}(\mathrm{kJ})}{\mathrm{M}_{\mathrm{w} \text { Tank }}(\mathrm{kg}) \cdot \mathrm{C}_{\mathrm{p}}\left(\mathrm{kJ} / \mathrm{kg}^{\circ} \mathrm{C}\right)}
$$

From the First Law for Thermodynamics applied to a steam compression refrigeration cycle, Eq.8, and the definition of COP, Eq.1, it can be deduced that $\mathrm{Q}_{\mathrm{cond} \text { (i) }}$, depends on: $\mathrm{CD}_{(\mathrm{i})}$, and the $\mathrm{COP}_{\mathrm{w}(\mathrm{i})}$; Eq.9. 


$$
\mathrm{Q}_{\text {Cond } \mathrm{W}(i)}=\mathrm{CD}_{(\mathrm{i})}\left(1+\frac{1}{\mathrm{COP}_{\mathrm{w}(\mathrm{i})}}\right)
$$

The $\Delta T_{T-T W}$ is calculated taking into account: $T W D_{(i)}$, the temperature increment allowed in the cold water supplied to the building, when passing through the heat exchanger located in the tank, $\Delta T_{T w}, M_{w T a n k}$, and the water density, $\rho_{\mathrm{w}}$, Eq.10.

$$
\Delta \mathrm{T}_{\mathrm{T}-\mathrm{TW}(\mathrm{i})}\left({ }^{\circ} \mathrm{C}\right)=\frac{\mathrm{TWD}_{(\mathrm{i})}\left(\mathrm{m}^{3}\right) \cdot \Delta \mathrm{T}_{\mathrm{TW}}\left({ }^{\circ} \mathrm{C}\right) \cdot \rho_{\mathrm{W}}\left(\mathrm{kg} / \mathrm{m}^{3}\right)}{\mathrm{M}_{\text {wrTank }}(\mathrm{kg})}
$$

In this study, the maximum supply temperature of TW inside the building has been limited to $25^{\circ} \mathrm{C}$, so the $\Delta T_{T W}$ is calculated based on ( $T_{T W}$ in $)$ as Eq.11:

$$
\Delta \mathrm{T}_{\mathrm{TW}}\left[{ }^{\circ} \mathrm{C}\right] \cdot=25^{\circ} \mathrm{C}-\mathrm{T}_{\mathrm{TW} \text { in }}\left({ }^{\circ} \mathrm{C}\right)
$$

Regarding the water temperature of the tank at the end of each time period, $\mathrm{T}_{\text {Tank (i), }}$ Eq.6, it must be taken into account: it cannot drop below $T_{T W}$ in because it is cooled with it, Table 3 , and $25^{\circ} \mathrm{C}$ has been set as maximum limit.

NG consumption with water condensation at hour $\mathrm{i}, \mathrm{NGC}_{\mathrm{w}}$ (i), can be calculated with: $\mathrm{CD}_{(\mathrm{i})}$, the COP obtained each hour with water condensation, $\mathrm{COP}_{\mathrm{W} \text { (i) }}, \mathrm{NCV}_{\mathrm{NG}}$, and the efficiency of NG engine, Eq.12, the daily NGC, NGC (d) $_{\text {, }}$ is calculated with the corresponding sum, Eq.13.

$$
N G C \cdot w_{(i)}=\frac{C D_{(i)}}{\operatorname{COP}_{w(i)} \cdot N V_{N G} \cdot \text { Engine Efficiency }}
$$


$\mathrm{NGC}_{\mathrm{w}(\mathrm{d})}=\sum_{\mathrm{i}} \mathrm{NGC}_{\mathrm{w}(\mathrm{i})}$

In summary, the calculation of $\mathrm{NGC}_{(\mathrm{d})}$ follows several steps: (1) to estimate $\mathrm{CD}_{(1)}$ and $\mathrm{TWD}_{(1)}$, (2) to know $\mathrm{T}_{\mathrm{Tank}(0)}$, (3) to calculate $\mathrm{COP}_{\mathrm{W}(1)}$, (4) to calculate $\mathrm{Q}_{\text {cond W (1) }}$, (5) to calculate $\Delta \mathrm{T}_{\mathrm{T} \_ \text {cond (i), }}(6)$ to calculate $\Delta \mathrm{T}_{\mathrm{T}} \mathrm{TW},(7)$ to calculate $\mathrm{T}_{\mathrm{Tank}}(1)$, (8) to calculate $\mathrm{NGC}_{(1)},(9)$ to repeat the process for the following hours, and (10) to make the sum of all the $\mathrm{NGC}_{(\mathrm{i})}$ values.

In these calculations, the power consumption caused by the new pumps installed in the water condensation system was not considered; because as initial estimate it is assumed that this is compensated by the reduction in consumption that occurs when fans of the chiller air condensation system stop.

\section{Results and discussion}

The Fig 6 (a-b) gives the results of: $\mathrm{COP}_{a}(\mathrm{i}), \mathrm{COP}_{\mathrm{w}}(\mathrm{i}), \mathrm{NGC}_{\mathrm{a}}$ (i) and $\mathrm{NGC}_{\mathrm{w} \text { (i) }}$ for the two months of minimum and maximum cooling demand (May and July) and Fig 7 shows $\mathrm{T}_{\text {Tank (i) }}$ Over the six months in which the building demands cooling (May to October).

Figure 6. Hourly COP and NGC of air and water condensation for the two months of minimum and maximum cooling demand

Figure 7. Hourly temperature of the fire water tank for the six month with cooling demand. 
From the analysis of Fig 6 it can be deduced that: the $\mathrm{COP}_{w}$ is always higher to $\mathrm{COP}_{a}$, the $N G C_{w}$ is lower at all hours of the day to $\mathrm{NGD}_{a}$, and the operating regime of the chiller is more constant with the new condensing system, as it provides a more constant COP.

It seems that the $\mathrm{COP}_{\mathrm{a}}$ is variable along the day in every month; this is due to the variation of outside air temperature. However, the $\mathrm{COP}_{w}$ is constant in the coolest months (May, June and October), and variable in the hottest (July, August and September), this is because in the first case the TW is capable of absorbing all Qcond w (the condensation temperature does not change), but not in the second case, in which $\mathrm{T}_{\text {Tank }}$ increases throughout the day (see Fig 7). It can be seen that the maximum daily increase in T Tank occurs in July, this value being lower than $5^{\circ} \mathrm{C}$, in addition at any time of the day is lower than $25^{\circ} \mathrm{C}$ that has been established as maximum water temperature of the tank. In the warmer months, if this temperature rise over this value, is possible to use air condensation, and make use of auxiliary night cooling of the tank.

The Table 4 presents the results of daily and monthly calculations of: building $C D$, $\mathrm{NGC}_{\mathrm{a}}$ and $\mathrm{NGC}_{\mathrm{w}}$. Similarly, it is deduced that with the proposed new system of water condensation the annual NGC is reduced by $18.6 \%$.

Table 4. Results of air and water systems condensation systems.

\section{Cost analysis}


Considering that the cost of NG is about $0.095 € / \mathrm{kWh}$, the annual cost saving would be near $1300 €$. Furthermore, it must be taken into account that the cost of the NG has been increasing along the years and is expected to go on rising.

On the other hand, if this proposal would have been taken into account during the design phase of the building, the fire water tank and the chiller could have been placed closer to each other. In addition, the chiller would have been a water-cooled unit instead of an air-cooled one. And due to the $50 \mathrm{~m}^{3}$ fire water tank, the auxiliary water cooler could be noticeably smaller than a typical cooling tower. As a result, considering this proposal during the design phase of the building, the extra-cost could be estimated at $6800 €$, including pumps, piping, accessories, heat exchanger and auxiliary water cooler. According to these considerations, the return period would be about 5 years.

In this case, due to the building and facilities previous design, it would be necessary an expensive piping system since the chiller and the fire tank are $90 \mathrm{~m}$ far from each other. In addition to this, new elements such as a water condenser should be installed. Thus, the investment could be about $20000 €$, that is, the return period would be longer than 15 years.

Finally, maintaining this system would not be different from maintaining a typical watercooled chiller and a typical fire water tank. If anything, cleaning the heat exchangers should be thoroughly done.

The maximum expected fire water temperature, about $21^{\circ} \mathrm{C}$, would require a detailed study about biological activity and its effects on the system performance. Growth rates of species of algae depend on the temperature, having been observed several differences between species for growth at low and high temperature ${ }^{65}$. 


\section{Sensitivity analysis}

This study was completed by performing a sensitivity analysis that takes into account three aspects, these are:

- change in building water demand, WD (+/- 10\%).

- variation in urban water supply temperature, $\mathrm{T}_{\mathrm{TW}}$ in, of $\left(+/-1^{\circ} \mathrm{C}\right)$.

- variation of the maximum temperature of the domestic water supply inside the building, $\mathrm{T}_{\mathrm{TW}},\left(+/-1^{\circ} \mathrm{C}\right)$.

The results obtained are shown in Table 5.

Table 5. Sensitivity analysis varying: water demand (WD), inlet temperature of domestic water in the building ( $\mathrm{T}_{\mathrm{TW}}$ in $)$, and temperature of distribution domestic water in the building ( $\left.\mathrm{T}_{\mathrm{TW} \mathrm{db}}\right)$.

The result of this analysis shows that: (1) with all the changes considered the current energy consumption of the facility with air condensation is improved, (2) in the months

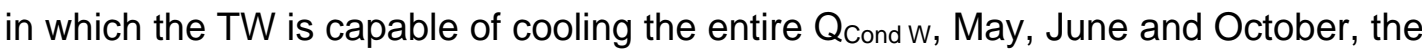
variations in WD in the building and in $\mathrm{T}_{\mathrm{TW}}$ in do not change the energy consumption, (3) changes of $+/-10 \%$ in WD make performance improvement to change by approximately $+/-1.0 \%$, (4) changes of $+/-1^{\circ} \mathrm{C}$ in $\mathrm{T}_{\mathrm{TW}}$ in make performance improvement to change by approximately $+/-3.85 \%$, and (5) changes of $+/-1^{\circ} \mathrm{C} \mathrm{T}_{\mathrm{TW}}$ make performance improvement to change by approximately $+/-1.22 \%$.

Finally, a 10\% increase in the CD of the building has been considered. As previously mentioned, the average data shown in Table 3 have been obtained from the Facilities Service of the University. The deviation of these data suggests the study of this proposal considering a $10 \%$ hotter summer. In this case, in addition to calculate the 
NGD of the system with water condensation, $N G D_{w}$, it is necessary to recalculate the NGD that would occur with air condensation, NGDa. The results are shown in Fig 8. $\mathrm{NGC}_{\mathrm{a}}$ would be $7607 \mathrm{Nm}^{3}$, while $\mathrm{NGC}_{\mathrm{w}}$ would be $6304 \mathrm{Nm}^{3}$.

Figure 8. Monthly Natural Gas Demand when considering a 10\% increase in building thermal demand.

The analysis of these results shows that a $10 \%$ increase in CD reduces the energy improvement of the proposed system to $17.1 \%$, while net savings increase. This is because in the warmer months the water condensation system is already saturated, and therefore this demand increase should be reached with the air condenser. The net saving occurs in the months coolest months, in which the water condensation can absorb more heat than the one would be eliminated by the chiller condensation.

\section{Conclusions}

The study presented in this paper has considered the use of the TW consumed in a University building to cool the condenser of the chiller, which provides the cooling used for air conditioning in the building. Due to the difference between cooling needs and the water consumption, the use of the fire water tank has been proposed for heat storage.

The results reveal that performing the condensation at low temperatures the COP of the chiller increases, which produces several beneficial effects: (1) the annual energy consumption of the chiller is reduced, in this case $18.6 \%$, (2) the heat removed in the condenser is reduced, (3) the chiller operation becomes more stable, and (4) the chiller 
is operated under lower condenser pressure conditions. These two effects contribute to extend the useful life of the chiller.

The sensitivity analysis performed in this work considered aspects such as: (1) change in building water demand, $+/-10 \%,(2)$ variation in urban water supply temperature, $+/-$ $1^{\circ} \mathrm{C}$, (3) variation of the maximum temperature of the domestic water supply inside the building, $+/-1^{\circ} \mathrm{C}$, and finally (4) increase in building cooling demand of $10 \%$.

\section{References}

1. Perez-Lombard L, Ortiz J, Pout C, A review on buildings energy consumption information, Energy and Buildings, 2008, 40, 394-398

2. DIRECTIVE 2010/31/EU of the European Parliament and of the Council of 19 May 2010 , on the energy performance of buildings

3. Perez-Lombard L, Ortiz J, Maestre IR, The map of energy flow in HVAC systems, Applied Energy, 2011, 88, 5020-5031

4. IDAE, http://www.idae.es/ 2014-Jun-02

5. Al-Rabghi OM, Akyurt MM, A survey of energy efficient strategies for effective air conditioning, Energy Conversion and Management, 2004, 45, 1643-1654

6. Chua KJ, Chou SK, Yang WM, Yan J, Achieving better energy-efficient air conditioning - A review of technologies and strategies, Applied Energy, 2013, 104, 87-104

7. O'Brien W, Kapsis K, Athienitis AK, Manually-operated window shade patterns in office buildings: A critical review, Building and Environment, 2013, 60, 319-338

8. Park M, Hagishima A, Tanimoto J, Narita K, Effect of urban vegetation on outdoor thermal environment: Field measurement at a scale model site; Building and Environment, 2012, 56 38-46 
9. Baetens R, Jelle BP, Gustavsen A, Properties,requirements and posibilitéis of smart windows for dynamic daylight and solar energy control in buildings: A state-of-the-art review. Solar Energy Materials \& Solar Cells, 2010, 94, 87-105

10. Abdullah A, Meng Q, Zhao L, Wang F, Field study on indoor termal environment in an atrium in tropical climates, Building and Environment, 2009, 44, 431-436

11. Catan A, Keumala N, Rao SP, Abdul-Samad Z, Experimental determination of thermal performance of glazed façades with water film, under direct solar radiation in the tropics, Building and Environment, 2011, 46, 2238-2246

12. He J, A design supporting simulation system for predicting and evaluating the cool microclimate creating effect of passive evaporative cooling walls, Building and Environment, 2011, 46, 584-596

13. Yau YH, Ahmadzadehtalatapeh $\mathrm{M}$, The empirical study of a four-row heat pipe heat exchanger to predict the year-round energy recovery in the tropics, Building Services Engineering Research and Technology, 2011, 32 (4), 307-327

14. Mardiana-Idayu A, Riffat SB, Review on heat recovery technologies for building applications, Renewable and Sustainable Energy Reviews, 2012, 16, 1241-1255

15. Gong G, Zeng W, Wang L, Wu C, A new heat recovery technique for airconditioning/heat-pump system, Applied Thermal Engineering, 2008, 28, 2360-2370

16. Renedo CJ, Ortiz A, Mañana M, Delgado F, A more efficient design for reversible air-air heat pumps, Energy and Buildings, 2007, 39, 1244-1249

17. Ghiaus C, Allard F, Potential for free-cooling by ventilation, Solar Energy, 2006, 80, $402-413$

18. Comentarios RITE 2007, Instituto para la Diversificación y Ahorro de la Energía, IDAE, Madrid, 2007. In Spanish.

Avalible at:

http://www.idae.es/index.php/mod.documentos/mem.descarga?file=/documentos_1054

0_Comentarios_RITE_GT7_07_2200d691.pdf 
19. Waqas A, Din ZU, Phase change material (PCM) storage for free cooling of buildingsA review, Renewable and Sustainable Energy Reviews, 2013, 18, 607-625

20. Santamouris $M$, Sfakianaki $A$, Pavlou $K$, On the efficiency of night ventilation techniques applied to residential buildings, Energy and Buildings, 2010, 42, 1309-1313

21. Kim MH, Kim JH, Kwon OH, Choi AS and Jeong JW, Energy conservation potential of an indirect and direct evaporative cooling assisted $100 \%$ outdoor air system, Building Services Engineering Research and Technology, 2011, 32 (4), 345-360

22. Santamouris $M$, Kolokotsa $D$, Passive cooling dissipation techniques for buildings and other structures: The state of the art, Energy and Buildings, 2013, 57, 74-94

23. Qiun GQ, Riffat SB, Novel design and modelling of an evaporative cooling system for buildings, International Journal of Energy Research. 2006; 30:985-999

24. Liu X, Hong T, Comparison of energy efficiency between variable refrigerant flow systems and ground source heat pump systems, Energy and Buildings, 2010, 42, 584589

25. Underwood CP, Spider JD, Analysis of vertical ground heat exchangers applied to buildings in the UK, Building Services Engineering Research and Technology 2007, 28 (2) , 133-159

26. Xiangguo $X$, Chao S, Shiming D, Using two parallel connected compressors to implement a novel control algorithm for improved indoor humidity at a low cost, Building Services Engineering Research and Technology, 2012, 34 (3) 349-354

27. Ekren O, Sahin S, Isler Y, Comparison of different controllers for variable speed compressor and electronic expansion valve, International Journal of Refrigeration 2010, $33(6), 1161-1168$

28. Chinnaraj C, Govindarajan P, Vijayan R, Influence of electronic expansion valve on the performance of small window air conditioner retrofitted with R407C and R290, Thermal Science, 2011, 15, 327-339 
29. Zhou YP, Wu JY, Wang RZ, Shiochi S, Li YM; Simulation and experimental validation of the variable-refrigerant-volume (VRV) air-conditioning system in EnergyPlus, Energy and Buildings, 2008, 40, 1041-1047

30. Aynur TN, Variable refrigerant flow systems: A review, Energy and Buildings, 2010, $42,1106-1112$

31. Chinnaraj C, Vijayan R, Govindarajan P, Analysis of Eco friendly Refrigerants Usage in Air-Conditioner, American Journal of Environmental Sciences, 2011, 7 (6), 510-514, 2011

32. Balghouthi M, Chahbani MH, Guisan A, Feasibility of solar absorption air conditioning in Tunisia, Building and Environment, 2008, 43, 1459-1470

33. Hassan HZ, Mohamad AA, A review on solar cold production through absorption technology, Renewable and Sustainable Energy Reviews 2012, 16, 5331-5348

34. Lu ZS, Wang RZ, Xia ZZ, Lu XR, Yang CB, Ma YC, Ma GB, Study of a novel solar adsorption cooling system and a solar absorption cooling system with new CPC collectors, Renewable Energy, 2013, 50, 299-306

35. Popli S, Rodgers P, Eveloy V, Trigeneration scheme for energy efficiency enhancement in a natural gas processing plant through turbine exhaust gas waste heat utilization, Applied Energy 2012, 93, 624-636

36. Beccali M, Finocchiaro $\mathrm{P}$, Nocke B, Energy performance evaluation of a demo solar desiccant cooling system with heat recovery for the regeneration of the adsorption material, Renewable Energy, 2012, 44, 40-52

37. ASHRAE Systems and Equipment Handbook (SI), Ch 36, Cooling towers, 2000

38. Guía técnica de torres de refrigeración, Instituto para la Diversificación y Ahorro de la Energía, IDAE, Madrid, 2007. In Spanish 
available at:

http://www.minetur.gob.es/energia/desarrollo/EficienciaEnergetica/RITE/Reconocidos/ Reconocidos/5Guia_4.pdf

39. Streng A, Combined wetidry cooling towers of cell-type construction, Journal of Energy Engineering, 1998,124:104-121

40. Macek K, Marík K, A methodology for quantitative comparison of control solutions and its application to HVAC (heating, ventilation and air conditioning) systems, Energy, $2012,44,117-125$

41. Ma Z, Wang S, An optimal control strategy for complex building central chilled water systems for practical and real-time applications, Building and Environment, 2009, 44, 1188-1198

42. Ma Z, Wang S, Energy efficient control of variable speed pumps in complex building central air-conditioning systems, Energy and Buildings, 2009, 41, 197-205

43. Gao D, Wang S, Sun $Y, A$ fault-tolerant and energy efficient control strategy for primary-secondary chilled water systems in buildings, Energy and Buildings, 2011, 43, 3646-3656

44. Ma Z, Wang S, Test and evaluation of energy saving potentials in a complex building central chilling system using genetic algorithm, Building Services Engineering Research and Technology, 201132 (2), 109-126

45. Woolley J, Harrington C, Modera M, Swimming pools as heat sinks for air conditioners: Model design and experimental validation for natural thermal behavior of the pool", Building and Environment, 2011, 46, 187-195

46. Paksoy HO, Gurbuz Z, Turgut B, Dikici D, Evliya H, Aquifer thermal storage (ATES) for airconditioning of a supermarket in Turkey, Renewable Energy, 2004, 29, 1991-1996 
47. Chua KJ, Chou SK, Yang WM, Yan J, Achieving better energy-efficient air conditioning - A review of technologies and strategies, Applied Energy, 2013, 104, 87104

48. Al-Abidi AA, Mat SB, Sopian K, Sulaiman MY, Lim CH, Abdulrahman Th, Review of thermal energy storage for air conditioning systems, Renewable and Sustainable Energy Reviews, 2012, 16 (8), 5802-5819

49. Furusawa K, Sugihara H, Tsuji K, Economic Evaluation of Demand-Side Energy Storage Systems by Using a Multi-Agent-Based Electricity Market, Electrical Engineering in Japan, 2009, 167 (3), 36-45

50. Renedo CJ, Ortiz A, Carcedo J, Air Conditioning Systems: Performance, Environment and Energy Factors, Ch 8 Improving design in reversible heat pumps, Nova Publisher, New York, 2010

51. F.P. Incropera, D.P. DeWitt, Fundamentals of heat and mass transfer", John Wiley and Sons, Inc. 1996

52. ASHRAE Applications Handbook, Ch 48, Service water heating, 1999

53. Fernández I, Renedo CJ, Pérez S, Ortiz A, Mañana M, A Review: Energy Recovery in Batch Processes, Renewable and Sustainable Energy Reviews, 2012, 16, 2260 2277

54. ASHRAE, Fundamentals Handbook (SI), Ch 27, Climatic Design Information, 2001 55. Instituto estatal de meteorología, http://www.aemet.es/es/portada 56. AENOR, UNE 100-014: Climatization, limit weather conditions for projects, 2001, In Spanish

57. Climaveneta COMMERCIAL AND INDUSTRIAL SYSTEMS, 2007; (GCH 03010901 Chiller Technical Data)

58. Internal Data, Servicio de instalaciones de la Universidad de Cantabria 
59. AENOR, UNE 94002:2005, Thermal solar systems for domestic hot water production. Calculation method for heat demand, 2005

60. ASHRAE Fundamentals Handbook (SI), Ch 29, Nonresidential Cooling and Heating Load Calculation Procedures, 2001

61. Spurr M, Larsson I, integrating district cooling with combined heat and power, IEA ,1996

62. ENAGAS, Spanish Natural Gas Transport Network, http://www.enagas.es/

63. Manual for calculating CHP electricity and heat, Protermo, 1999

64. Pita EG, Refrigeration Principles and Systems: An Energy Approach, John Wiley \& Sons, USA, 1984

65. Butterwick C, Heaney S I, Talling F J, Diversity in the Influence of Temperature on the Growth Rates of Freshwater Algae, and its Ecological Relevance, Freshwater Biology, 2005, 50, 291-300

\section{List of figure legends}

Figure 1. Spanish energy consume in buildings

Figure 2. Plan and elevation of the building

Figure 3. Design scheme of the proposed system

Figure 4. Scheme of the immersion heat exchanger in the fire water tank

Figure 5. Profiles of daily demands for cooling and domestic water

Figure 6. Hourly COP and NGC of air and water condensation for the two months of minimum and maximum cooling demand 
Figure 7. Hourly temperature of the fire water tank for the six month with cooling demand

Figure 8. Monthly Natural Gas Demand when considering a 10\% increase in building thermal demand. 